\title{
PUBLIC-PRIVATE PARTNERSHIPS: ORIGIN, LIMITATIONS AND PROSPECTS FOR PUBLIC SECTOR ACCOUNTING ${ }^{12}$
}

\author{
Nyalle Barboza Matos ${ }^{3}$ \\ Andréa de Oliveira Gonçalves ${ }^{4}$
}

http://dx.doi.org/10.1590/1413-2311.279.98525

\begin{abstract}
The main objective of this research is to identify and discuss theoretically the advances, limitations and perspectives pointed by international research to improve the accountability and evaluation aspects of PPPs. This is a theoretical essay based on the Public Choice Theory to show that the PPP accounting treatment is relevant to avoid lack of transparency and accountability, mitigating possible losses in the decision-making process and the ineffective allocation of public resources. The discussion of topics reveals the importance of public accounting in measuring the financial and social consequences that the shared responsibility of PPPs can have, defending the public interest and democratic relations. It is argued that different factors may influence PPP accounting issues, involving governance limitations, institutional weaknesses, widespread corruption, lack of transparency, weak regulatory environments, power imbalances between partners, lack of political commitment and trust. Finally, some accounting research questions and topics are presented that should be considered to prevent private interest from overriding the public interest in contracting a PPP.

\footnotetext{
${ }^{1}$ Recebido em 26/11/2019, aceito em 6/3/2020.

${ }^{2}$ O presente artigo foi realizado com apoio da Coordenação de Aperfeiçoamento de Pessoal de Nível Superior CAPES - código de financiamento 001. Esta pesquisa é parte integrante de uma tese em elaboração pelo PPGCONT/UnB.

${ }^{3}$ Universidade de Brasília - Programa de Pós-Graduação em Ciências Contábeis (PPGCont); Brasília - DF (Brasil); http://orcid.org/0000-0002-5006-661X; nyallematos@ @otmail.com

${ }^{4}$ Universidade de Brasília - Programa de Pós-Graduação em Ciências Contábeis (PPGCont); Brasília - DF (Brasil); https://orcid.org/0000-0001-7514-8139; andreaegoncalves@ gmail.com
}

(ㄷ) $(1) \Theta\left(\right.$ REAd | Porto Alegre - Vol. 26 - N. ${ }^{\circ} 1$ - Janeiro / Abril 2020 - 114-136. 
Keywords: Public-private Partnerships. Accountability. Public Choice. Public Governance.

\section{PARCERIAS PÚBLICO-PRIVADAS: SURGIMENTO, LIMITAÇÕES E PERSPECTIVAS PARA A CONTABILIDADE PÚBLICA}

Esta pesquisa tem como objetivo central identificar e discutir sob o aspecto teórico os avanços, limitações e perspectivas apontados por pesquisas internacionais para melhorar a prestação de contas e os aspectos de avaliação das PPPs. Trata-se de um ensaio teórico, baseado na Teoria da Escolha Pública para evidenciar que o tratamento contábil das PPP é relevante para evitar a falta de transparência e responsabilização, amenizando possíveis prejuízos no processo de tomada de decisão e a alocação ineficaz de recursos públicos. A discussão dos tópicos revela a importância da contabilidade pública em mensurar as consequências financeiras e sociais que a responsabilidade compartilhada das PPPs pode causar, defendendo o interesse público e as relações democráticas. Argumenta-se que diferentes fatores podem influenciar questões contábeis sobre PPPs, envolvendo limitações de governança, fraquezas institucionais, corrupção generalizada, falta de transparência, ambientes regulatórios fragilizados, desequilíbrios de poder entre os parceiros, falta de compromisso político e de confiança. Por fim, são apresentados alguns questionamentos e tópicos de pesquisas contábeis que deveriam ser considerados para impedir que o interesse privado se sobressaia sobre o interesse público na contratação de uma PPP.

Palavras-chave: Parcerias Público-privadas. Accountability. Escolha Pública. Governança Pública.

\section{ASOCIACIONES PÚBLICO-PRIVADAS: ORIGEN, LIMITACIONES Y PERSPECTIVAS PARA LA CONTABILIDAD PÚBLICA}

El objetivo principal de este estudio fue identificar y discutir teóricamente los avances, limitaciones y perspectivas señaladas por la investigación internacional para mejorar los aspectos de responsabilidad y evaluación de las APP. Este es un ensayo teórico basado en la Teoría de la elección pública para mostrar que el tratamiento contable de las APP es relevante para evitar la falta de transparencia y responsabilidad, mitigando las posibles pérdidas en el proceso de toma de decisiones y la asignación ineficaz de los recursos públicos. La discusión de los temas revela la importancia de la contabilidad pública en la medición de las (c) $\left(\right.$ (1) $\Theta$ REAd | Porto Alegre - Vol. 26 - N. ${ }^{\circ} 1$ - Janeiro / Abril 2020 - 114-136. 
consecuencias financieras y sociales que puede tener la responsabilidad compartida de las APP, defendiendo el interés público y las relaciones democráticas. Se argumenta que diferentes factores pueden influir en los problemas de contabilidad de las APP, que incluyen limitaciones de gobierno, debilidades institucionales, corrupción generalizada, falta de transparencia, entornos regulatorios débiles, desequilibrios de poder entre los socios, falta de compromiso político y confianza. Finalmente, se presentan algunas preguntas y temas de investigación contable que deben considerarse para evitar que el interés privado anule el interés público en la contratación de una APP.

Palabras clave: Asociaciones público-privadas. Accountability. Elección pública. Gobernanza Pública.

\section{INTRODUCTION}

Globalization makes multiple actors interact with the state and share their functions. This sharing does not lead to the end of the state, but rather stimulates a series of government and governance strategies in a more activist state (ANGELIS, 2015). The involvement of other actors in the public administration, either private or from the civil society, again emphasizes the need to conceptualize the diversity of the public sector (PETERS; PIERRE, 2010).

It is in this context that more than twenty years ago the term Public-Private Partnership (PPP) was conceptualized. From a global perspective, PPPs are viewed as an alternative form of financing and management to be used in addition to or complementary to other instruments to address infrastructure and service needs across a wide range of sectors, from environmental services to health or education (HODGE; GREVE, 2005).

This topic has been developing in recent years, with increasing research seeking to elucidate a range of PPP-related issues, ranging from overviews to industry-specific approaches, revealing aspects of efficiency measurement to institutional factors that favor its implementation. Despite this effort, it is still necessary to reexamine the different meanings and definitions given to PPPs to analyze their domain and their theoretical structure (MARSILIO; CAPPELLARO; CUCCURULLO, 2011).

In research agendas that address the PPP approach from an accounting perspective, some papers (CAPERCHIONE; DEMIRAG; GROSSI, 2017; HODGE; BOARDMAN, 2017a) question the role that accounting should play as part of the development and adoption of PPP projects. In this sense, accounting needs to be part of the decision process that leads to the adoption of any asset delivery model, evidencing not only a clear understanding of the 
values involved in hiring, but also its limitations, origins, construction and interpretation (OPARA; ROUSE, 2018).

Moreover, PPP accountability involves many technical and difficult to understand terms (engineering, budgetary and legal aspects) that make accountability and its understanding difficult (ANDON, 2012). In addition to this common difficulty in understanding the language of such a complex contract, it is considered that the long-term feature and high specificity of PPPs involve high risks to the public sector (ANDON, 2012).

Another important issue has to be considered: the public interest that must underlie democratic responsibilities with regard to community service (GRIMSEY, LEWIS, 2002). Following this logic, protection of the public interest should be considered in the evaluation of partnerships in order to guide practices that clarify a list of issues such as: partnership agreements preserve the right of citizens to be well informed about government and private sector partner obligations, and can these be supervised? Could those affected citizens contribute constructively to the partnership planning? Are adequate governance arrangements in place to ensure that disadvantaged groups can effectively use services? (GRIMSEY; LEWIS, 2002).

Acknowledging this gap in the literature arises the research problem that this theoretical study seeks to clarify: what are the limitations and perspectives faced by the public sector accounting to improve the accountability and evaluation aspects of PPPs? The main objective that this study proposes is to identify and discuss theoretically the advances, limitations and perspectives pointed by international research to improve the accountability and evaluation aspects of PPPs. It is believed that a theoretical approach can promote the accumulation of knowledge on the subject, clarifying the role of PPPs in the provision of public services and infrastructure, discussing the main problems cited in the literature and contributing to the adaptation of public sector accounting to the new challenges of reporting.

This theoretical essay was elaborated from a narrative review and the establishment of propositions about the advances, limitations and perspectives that the public sector accounting will have in order to improve the quality of the information provided in the reporting and to follow the new trends of the State. This review model is indicated when researchers seek to synthesize current knowledge on a given subject, from a general perspective. The study delimitation considered seminal articles and books in the area, including the most recent publications in international journals.

The originality of this paper resides in two main points: 1) it presents a more recent discussion of international literature on the challenges that emerge in the accounting and evaluation of PPPs; and 2) it seeks to stimulate the debate on PPPs in Brazil, which despite not yet presenting academic data on the subject, a journalistic study showed that of the 53 federative entities (states and municipalities) that have active contracts, 42 do not record 
payments in their balance sheets or are breaking tax rules. Only five of them meet the requirements set by the Treasury and the others partially meet them (HIRATA, 2018).

The theoretical approach of this paper surrounds Public Choice Theory to justify movements such as New Public Management and New Public Governance on which the emergence of PPP is based. This theory attributes a less altruistic treatment to the functions of the state and defends the current conjuncture for the creation of hybrid and cooperative structures between different actors that thereafter operate with the state in increasingly globalized institutional relations.

This paper is structured in four sections besides this introduction: the first will address state redesign from the perspective of public sector reform movements, which envisages the possibility for other non-governmental actors to participate in providing infrastructure and providing public services. The second section addresses the emergence of PPPs, their concepts and key challenges through the possibility of carrying out social and economic activities that were previously considered to be strictly state functions. The third section establishes, from the perspective of accountability, the challenges and perspectives that public sector accounting faces to accompany the need for information between public and private partners (and society's needs). The fourth section discusses the changes and challenges of PPP accounting in the light of public choice theory, summarizing the main questions raised in the previous section.

\section{REFORM ENVIRONMENTS IN THE PUBLIC SECTOR: MULTIPLE ACTORS INTERACTING WITH THE STATE}

As a result of the scarcity of resources and the economic crisis facing European states, many of the administrative reforms that took place between the 1980s and 1990s were centered on the pursuit of economy and efficiency in the public sector (HOOD, 1991). The background behind these improvement proposals was to restore levels of government confidence lost in the decline of the welfare state. Motivated by this need for changes in the state, a movement called New Public Management (NPM) emerged, which suggests a different conception of public responsibility, reducing or removing differences between the public and private sector and shifting the focus of the process of accountability and directing the state towards efficient and effective results (HOOD, 1991).

The NPM movement has been criticized in many ways, specially for its overly intraorganizational focus on an increasingly plural world, and for its adherence to the application of outdated private sector techniques for public policy implementation and public service delivery (OSBORNE, 2009). This market oriented and efficient results approach was also criticized for being less representative of the public interest from a democratic point of view. 
The criticism of the excessive focus on efficient results only by the economic point of view was responsible for the emergence of the concept of a more pluralistic state, where there is a focus in the interorganizational relations and public governance, emphasizing the effectiveness of the services and more efficient results also from the point of view of the citizen (OSBORNE, 2009). The rise of pluralism in the public sector replaces the notion of the state as the sole provider of public goods and services and gives rise to a movement toward interdependence among actors.

In this global context, the New Public Governance (NPG) is being presented as a conceptual tool with the potential to help the understanding of the complexity of the challenges of a globalized and pluralistic State of the XXI century (POLLIT; BOUCKAERT, 2011). One of the most noticeable changes in this movement is made when the state no longer occupies a clear position of authority, viewed as a top-down, hierarchical process. In the metaphorical conception of NPG, the state becomes just one player among many others in the political arena (OSBORNE, 2009). Thus, the political arena has become noticeably more crowded and contested, there are more actors involved, the boundaries between the public and the private are less precise, and the government's command over the political process is constantly changing (OSBORNE, 2009).

The hybridization between organizations proposed by NPG refers to interorganizational forms that merge functions, structures, resources and knowledge and management systems that operate in the gray area between the public and private sectors and have to combine objectives, values, obligations, identities, orientations and potentially conflicting cultural aspects if viewed from the perspective of different institutional logics (public, private and third sector) (HODGE; GREVE; BOARDMAN, 2017). From this institutional rearrangement, problems can arise regarding risk control and transfer systems, as well as interference with the role of mutual trust between private and public sector organizations.

NPG's main assumptions fit the PPP agenda like a glove: the adoption of private sector's technical and market competition; better elaborated contracts; better performance measurement systems; better formalized objectives; detailed output specifications; and focus on results (HODGE; GREVE; BIYGAUTANE, 2018). More broadly, the emergence of PPPs arose from a powerful ethos of prioritizing the efficient use of capital, based on the reliability of democratic processes to safeguard the public interest (HODGE; GREVE; BIYGAUTANE, 2018). Accordingly, to achieve this goal and not undermine the democratic values of the state, an efficient accountability tool is needed, which allows for the oversight of partnership objectives throughout the contract (OPARA; ROUSE, 2018). 


\section{THE EMERGENCE OF PUBLIC -PRIVATE PARTNERSHIPS: CONCEPTS AND CHARACTERISTICS}

Although their advantages are prescribed in the literature, PPPs do not yet have a clear definition. Hodge and Greve (2007) state that PPPs are currently seen as the main alternative for public service procurement and privatization and are therefore considered a qualitative leap in the effort to join forces between the public and private sectors. The OECD (2014, p. 36) has defined PPPs:

As an agreement between the government and one or more private partners (which
may include operators and financiers), whereby private partners deliver the service
in such a way that the service delivery objectives are aligned with the profit
objectives of the private partners and where the effectiveness of the alignment
depends on sufficient risk transfer to the private partner. (OECD, 2014 p. 36)

Many authors have emphasized mutuality and sharing as key conceptual features of PPPs (MORAVIEV; KAKABADSE, 2016). These characteristics become important because they are a commitment that goes beyond the contract, they differentiate PPP from outsourcing or other traditional forms of public-private contracting. Collaboration and partnership across industries is the result of an effort to increase the efficiency and flexibility of organizations by providing a solution to one or more of the following issues: resource scarcity, risk distribution among partners, and operational inefficiency, therefore, each partner fills a gap in skills, resources and / or competencies in which the other partner shows difficulties managing alone (VILLANI;, GRECO; PHILLIPS, 2017).

The main institutional aspects raised in the PPP literature can be systematized into three categories: Financial (which includes project financing, risk sharing and revenue sharing), Legal (which involves contractual aspects, formalization of purpose specific entities, applicable laws and regulations) and organizational (with respect to division of tasks and responsibilities, formal decision-making requirements and project organization) (OSBORNE, 2009). In all these respects, it is observed that the long-term contract is what allows both partners to tend to benefit from cooperation and to produce a return on their initial investment and, in fact, to meet their interests.

It should also be stressed that governments must harness the strength of the private partner to achieve efficiency gains and choose the jurisdiction that best suits its purpose, adopting various contractual arrangements, different shares of risks, different mixtures of financing schemes, transparency and assumptions about the best way to deal with governance risks or outcomes (HODGE; GREVE; BOARDMAN, 2017). Another predominant feature is the fact that PPP deployment and execution processes are extremely complex as a result of the long-term, multi-stage legal nature (in terms of design, construction, operation and maintenance) (WANG et al., 2017). 
All the features and benefits of PPPs presented in this section are mixed when trying to understand their true motivation. According to Hodge, Greve and Biygautane (2018), it should be noted that PPPs can present themselves as both a political tool and a technical tool. Thus, while there is a possibility of interpreting them as part of an economic project that seeks efficiency in the allocation of public resources, it takes much responsability of the public sector to avoid democratic losses and risks (HODGE, GREVE, BIYGAUTANE, 2018).

\section{ACCOUNTABILITY IN PUBLIC-PRIVATE PARTNERSHIPS IN THE INTERNATIONAL CONTEXT}

The term accountability and its meaning bring with it a complex, abstract and multifaceted question that can be approached in different ways (FOMBAD, 2014). Historically, public sector accountability is related to control and reporting, whether exercised formally, through rules and laws, or indirectly by the society that oversees its elected representatives to act on its behalf (FORRER et al., 2010).

In the context of accountability and its implications, PPPs raise increasingly important questions of democratic governance due to the altered nature of the state when engaging in cooperative activities with private actors, and there may be a democratic deficit due to lack of accountability (BOATENG; STANDFFORD; STAPLETON, 2017). For this reason, the issue of accountability becomes more relevant, because since the investments are made in the long term and directly affect the rights and public interests, it is necessary to explain and show how public services through PPPs meet the substantive values of democracy (FOMBAD, 2014).

In an attempt to minimize this damage to developing countries, the OECD (2014) has set some key points to study and improve in relation to corruption and lack of transparency in PPP hiring and enforcement. These points include factors related to: information asymmetry between the contracting public authority and the private company that does not make sufficient data available to the government and citizens or use unconventional means to influence the bidding and contracting process; the possible conflict of interest and culture between civil servants acting in the service agency and employees of the private company; and, finally, the possibility of contracted companies financing politicians, who can use their influence to manipulate the bidding and give results favorable to their own interests (OECD, 2014).

Regarding accountability and the most relevant information to be disclosed and analyzed in relation to PPPs, three major characteristics can be considered: first, a thorough Value for Money (VfM) is needed to ensure effective processes for calculating adequately costs incurred in projects and implementation, as well as the risk shared between sectors; later on, emphasis needs to be placed on political accountability over PPP decision- 
making and enforcement; and finally, proper accounting treatment of PPPs is required (VIANA et al., 2017).

The fact that PPPs combine different institutional logics (market, civil society and government) requires greater efforts to generate solutions to solve the problem of who is responsible to whom, and there is no model properly ready to be applied in its design, considering the complexity of the relationships in which citizens became customers and the government now behaves as a buyer of utilities (VILLANI; GRECO; PHILLIPS, 2017). The institutional complexity they have to deal with can often lead to unintended consequences, which can impede the achievement of specific goals and value creation if not properly managed (VILLANI; GRECO; PHILLIPS, 2017).

Hybrid organizations operate partly in the market and partly in the public sector. In the marketplace, accountability is based on mechanisms that focus primarily on financial performance rather than on the creation of public and democratic values, which are the focus of public sector services. In this sense, there is also a challenge in analyzing and studying whether a system based on sufficient market and efficiency mechanisms are being sufficient to ensure accountability in hybrid bodies that are also subject to public sector values (GROSSI; THOMASSON, 2015).

Contract management is one of the most significant transaction costs for establishing governance and accountability in PPPs and is considered one of the most important factors in ensuring that the public interest is protected when goods and services are delivered by nonactors (BOYER; NEWCOMER, 2015). First, contract design requires estimates of how the private sector should be paid, and these estimates are based on forecasts of consumer demand (such as willingness to pay tolls), long-term operating costs and/or potential related service interruptions related to natural resources and possible contingencies. Another challenge is to establish the right means of performance appraisal based on key performance indicators, errors in this appraisal may lead to overestimation of risks or the actual involvement of the private sector in public service delivery or infrastructure construction (BOYER; NEWCOMER, 2015).

Reinforcing the criticism about lack of transparency and accountability, it can be argued that the available information about PPP is limited, inaccurate and insufficient (REYNAERS; GRIMMELIKHUIJSE, 2015). As a result of this deficiency, there is a lack of meaningful and understandable data. Transparency can be observed on two fronts: the external one translates the extent to which organizations are visible to society at large, and the internal one refers to how the private partner provides clarity on the processes and activities performed, informing their performance, risk and expectations to the public (REYNAERS; GRIMMELIKHUIJSE, 2015).

PPPs and their relationships thus establish a typical situation of information asymmetry, where transparency is key to ensuring that key players (public agencies and 
society) oversee agents (private companies) to ensure that the public interest is achieved, and the purpose of PPP is met. Aligning public-private interests is one of the most difficult tasks in formulating PPP contracts, as they may differ. To remedy this difficulty, it is increasingly necessary that studies on the accounting and financial data provided by current PPPs be analyzed to determine the degree of transparency offered, seeking possible explanations of the lack of accountability and transparency.

Analyzing the failures of transparency and accountability pointed out in the literature, it is clear that more and better regulation is needed. Control mechanisms must be in place to prevent inappropriate disclosure under the guise of commercial confidentiality. Accounting information should flow between partner organizations and society at large to ensure effective oversight of PPPs (CAPERCHIONE; DEMIRAG; GROSSI, 2017; HODGE; GREVE; BOARDMAN, 2017).

\subsection{INTERNATIONAL PERSPECTIVES TO IMPROVE ACCOUNTABILITY IN PPP CONTRACTS IN BRAZIL}

After discussing the importance of accountability and transparency in PPP contracts, discussing the accounting treatment of PPPs is a relevant process to avoid the lack of transparency and accountability related to assets and liabilities that may not be included in government balance sheets (VIANA et al., 2017). The discussion is also important to avoid inadequate disclosure of the long-term fiscal risks involved and the contingent liabilities that may be anticipated; and finally, to avoid prejudice to the decision-making process, which leads to inefficient allocation of public resources, given the incentives related to the achievement of fiscal targets rather than the PPP's VfM assessment (VIANA et al., 2017).

The public sector reforms cited in this essay lead to the conclusion that there are several challenges and opportunities for governments to use different accounting techniques and structures to reduce barriers and objections to such reforms. Producing a single financial report that covers all government activities, including PPPs, is a major accounting challenge (CAPERCHIONE; DEMIRAG; GROSSI, 2017).

Despite the high degree of uncertainty about the best accounting treatment for PPPs, the International Public Sector Accounting Standards Board (IPSASB) issued in 2011 the International Public Sector Accounting Standards 32, Service concession arrangements: Grantor (IPSAS 32, 2011). This standard has as its main focus of discussion the recognition of assets and liabilities arising from the public concession, which could consider two predominant criteria: an approach of risks and rewards or control over the object of the concession (HEALD; GEORGIOU, 2011; MOSCARIELLO; CINQUE, 2016). In the risk and reward approach, asset ownership rests with the party that bears the most risks and reaps the 
benefits, and it is up to the (grantor) government to record the associated assets and liabilities whenever it bears the most risks. In the second approach (adopted by IPSAS 32), ownership of the asset belongs to the party that controls or regulates the services or structure that the partner will have to bear (MOSCARIELLO; CINQUE, 2016).

The purpose of IPSAS 32 was to improve the assumptions previously set forth in the International Financial Reporting Interpretations Committee (IFRIC 12) standard by minimizing the possibility of an asset being accounted for by both parties involved in a PPP contract or by neither (HEALD; GEORGIOU, 2011). It is expected that the IPSAS 32 and its proposal to prevent government units from doing PPP agreements that exceed the debt ceilings. In Brazil, the Manual de Contabilidade Aplicado ao Setor Público - MCASP (2019, p. 276) (which is a manual for public sector accounting that is governamental issued) provides for the updated standardization of accounting procedures for Public Service Concessions prepared in accordance with the Norma Brasileira de Contabilidade (NBC TSP) 05 Acordos de Concessões de Serviços Públicos: Concedente (Brazilian Accounting Standard No. 5 - Agreements for Public Service Concessions: Grantor), from the Conselho Federal de Contabilidade (Federal Accounting Council), also complying with IPSAS 32 and applicable Brazilian law.

According to the Manual on Government Deficit and Debt (2016, p. 335), PPPs can create an illusion of accessibility (mainly due to the fact that public sector payments are diluted over time), and this illusion is reinforced when those responsible for public accounting do not disclose these liabilities in their public statements and balance sheets. Tax liabilities arising from PPPs can have a detrimental effect on the fiscal sustainability of the public agency and should be properly managed (including contingent liabilities, equity and revenue limits and full disclosure of amounts invested in PPP) (MGDD, 2016).

In the Brazilian context, the advent of PPPs only came to light with the publication of Law No. 11,079 of 12/30/2004 (amended by Law No. 13,529, of December 4, 2017). This Law establishes the basic conditions for the development and implementation of joint ventures between the public and private sectors, through public-private partnerships, being considered a kind of regulatory framework for this type of contracting. The recent changes that took place at the end of 2017 allows PPPs to have contracts of over R \$ 10 million and that lasts more than 5 years. Contracts that have as their object only the supply of labor, the supply and installation of equipment or the execution of public buildings are prohibited.

According to the MCASP (2019, p. 281), the public sector must

[...] [r]ecognize a concession asset when, in addition to the requirements for recognition of the asset - the likelihood that future economic benefits or potential service benefits from it will flow to the entity and the possibility that its cost or value will be determined on a reliable basis - all of the following requirements are present: a. The grantor controls or regulates the service object of the grant. $b$. The grantor has control or any significant residual interest in the asset at the end of the concession agreement term or the asset is used throughout its useful life (MCASP, 2019 p. 281). 
The MCASP (2019) is brief and objective in addressing PPP accounting, not mentioning how to proceed in relation to studies prior to contracting partnerships, nor the form of performance evaluation. Regarding the transparency and budgetary adequacy of PPPs, the Manual de Demonstrativos Fiscais (Manual of Fiscal Statements) (MDF, 2019) determines for all entities of the Brazilian federation to publish, every two months as part of the Relatório Resumido de Execução Orçamentária (Summary Budget Execution Report), a statement that reports the impacts of PPP contracting in the entity's accounts, specifically on the total of: Assets constituted; Liabilities, detailed in: Obligations arising from assets constituted by the Special Purpose Company, Provisions for PPP and Other Liabilities; Potential Acts Liabilities represented by Contractual Obligations of future consideration and Guarantees granted (MDF, 2019).

Although Brazilian law decides on risks, guarantees and other factors, a review of more specific and appropriate factors to Brazilian reality may still be necessary, as it appears that PPPs suffer high rates of delay and cancellation in the preceding stages of the signing of the contract due to various regulatory constraints or implementation failures (THAMER; LAZZARINI, 2015). As a result of this limitation, there are the few PPPs that are in the postcontractual phase in Brazil, which reduces the number of observations available for a study that analyzes partnerships during their construction or operational period (THAMER; LAZZARINI, 2015).

Another aspect of PPP contracts in Brazil is observed by Marques (2017), who analyzed, among other cases, the MG-050 highway contract, concluded by the state of Minas Gerais, Brazil, in 2007 and effective until the year 2032. Among the particularities of the contract, the author mentions that the partnership has had public complaints over the past few years due to increased tolls and delayed investment, which has been revised several times (although no significant sanctions have been applied). In this case, proper regulation should ensure that negotiations between the grantor and the concessionaire take place fairly, protecting stakeholders, and in particular the users. The rules for restoring financial equilibrium in Brazil do not offer direct compensation and, therefore, it is very likely that any change in investment will result in increased tolls or other fees (MARQUES, 2017).

By investigating the factors that influence PPP initiatives in Brazil, Thamer and Lazzarini (2015) analyzed 177 PPP projects developed in Brazilian states, highlighting the importance of creating and stimulating model-specialized agencies to interface with firms and define regulatory models to encourage private sector involvement from the outset of these projects. The results also indicated that PPPs advance faster in places with moderate level of corruption.

Although the current landscape of PPPs in Brazil has not been studied extensively in academic research, data show that in 2017, municipalities, state governments and the Union set a record for launched projects (with 281 elaborated projects) but only three were 
successful and had its contracts signed (MAXIMO, 2017). Assuming that Brazil should follow the global trend in infrastructure development through public-private partnerships, it is imperative to carry out national and international development plans to address the issues of accountability, design and contracting monitoring.

\section{LIMITATIONS AND CHALLENGES OF ACCOUNTABILITY OF PPPS: THE ROLE OF ACCOUNTING TO ENSURE THE PUBLIC INTEREST}

The theoretical tendency to use more market intervention and less state intervention can be explained by the Public Choice Theory (PCT) initially developed by Buchanan (1949) and defined as a view of political decisions without romanticism. For the author, democratic notions give rise to misconceptions that presume that participants in the political sphere aspire to promote the common good. Inspired to pursue the public interest, civil servants are portrayed as benevolent civil servants who faithfully perform what is called will of the people.

In the realistic view of this theory, the economic model of rational behavior predominates in which people are guided mainly by their own interests and, for this reason, rejects the construction of organic decision-making units, such as people, community or society, considering that only individuals make choices (BUCHANAN, 1999).

Research agendas indicate that the use of PPPs has been motivated as a means of increasing the effectiveness of public governance and its outcomes (CAPERCHIONE; DEMIRAG; GROSSI, 2017). However, from the perspective of the Public Choice Theory, partnerships can also be viewed as a financial venture or loan, which can be motivated purely for the purpose of maximizing political appeal to voters as a faster way to resolve conflicts (BRINKERHOFF; BRINKERHOFF, 2011).

Based on the foundations of PCT, one can understand the importance of the PPPs in terms of the particular interests of various agents, but not in the public interest as a whole. From the standpoint of elected politicians, for example, there is a tendency to expect to maximize their short-term reelection opportunities. From the standpoint of bureaucrats, there is a mixed utility of the public interest and their personal interest - the relevance of public interest in this utility function depends on the incentives they will receive to defend it (MONTEIRO, 2010). Still from the individual perspective of the agents, analyzing the parties involved in the PPPs, while politicians tend to disregard the long term and maximize their choices while in power, the private sector tends to be profit maximizers, exploiting the market opportunities (in which them may or may not have ethical concerns) (MONTEIRO, 2010).

Politicians know that there are some rules (legislation, budget and social control) that can restrict their ability to optimize the work done, as they face budget constraints (MONTEIRO, 2010). To circumvent this restriction and increase the likelihood of winning the next election, most public projects that could benefit users/citizens would have to be 
approved. This necessity causes elected politicians to tend to circumvent debt restrictions and ignore public spending limits.

Such a situation creates a problem of public choice, where the option to provide a service or build public infrastructure through PPP may result in lack of accountability in the short term. It is also noted that this problem is aggravated when considering the fact that PPPs do not generate public spending in the early years (because payments generally start only after infrastructure is completed) creating the false impression that the decision to opt for a partnership instead of a traditional hiring can be more advantageous (MONTEIRO, 2010).

In particular, the implications of PPPs accounting treatment (which involves resource management, performance appraisal and control) should be considered at all project phases to ensure better decisions and merit of partnerships throughout the contract (ANDON, 2012; OPARA; ROUSE, 2018). It is emphasized the need for research that reinforces the role of accounting not only as a facilitator of decision making in the hybrid structures of PPPs, but also as an instrument of accountability and social control. Table 1 summarizes some accounting questions and topics that should be considered to prevent private interest from overriding the public interest in contracting a PPP.

Table 1 - Reflections on the role of accounting to alleviate public choice problems in PPPs

\begin{tabular}{|c|c|}
\hline Accounting Topics Related to PPPs & Reflections in the light of Public Choice Theory \\
\hline $\begin{array}{l}\text { Recognition and disclosure of assets and liabilities } \\
\text { (ANDON, 2012; HEALD; GEORGIOU, 2011) }\end{array}$ & $\begin{array}{l}\text { Accounting standards should ensure an effective way } \\
\text { to measure and disclose assets and liabilities arising } \\
\text { from PPP contracts. In Brazil, are the requirements of } \\
\text { the Manual de Contabilidade e Manual de } \\
\text { Demonstrativos Fiscais being met in a timely and } \\
\text { clear manner (in accordance with the fundamental } \\
\text { characteristics of accounting information)? Are they } \\
\text { sufficient to prevent contracted PPPs from exceeding } \\
\text { established budget limits? }\end{array}$ \\
\hline $\begin{array}{l}\text { Accountability and transparency } \\
\text { (REYNAERS; GRIMMELIKHUIJSE, 2015; } \\
\text { BOATENG; STAFFORD; STAPLETON, 2017) }\end{array}$ & $\begin{array}{l}\text { The accounting information contained in the } \\
\text { statements and reports must be available and easily } \\
\text { accessible. In addition to the availability of this } \\
\text { information, comprehensibility may be affected by } \\
\text { some factors due to the amount of technical and } \\
\text { specialized requirements that the contract may bring. } \\
\text { According to the assumptions of Agency Theory, the } \\
\text { amount of layers between society and government } \\
\text { can lead to a higher level of information asymmetry, } \\
\text { greater conflicts and agency costs. }\end{array}$ \\
\hline $\begin{array}{l}\text { Evaluation of the merits of PPPs in the contracting } \\
\text { phase (VILLANI, GRECO, PHILLIPS, 2017). }\end{array}$ & $\begin{array}{l}\text { From a managerial point of view, where accounting } \\
\text { information supports decision-making, the correct } \\
\text { risk and benefit measures that PPPs may cause } \\
\text { throughout the long-term contract must be } \\
\text { observed. Initial studies on the feasibility and merit } \\
\text { of PPPs should take into account the budgetary and } \\
\text { fiscal impacts that potential obligations will entail. In } \\
\text { addition, stakeholder participation should be } \\
\text { considered in partnership planning and appropriate } \\
\text { governance arrangements that make it work while } \\
\text { preserving democratic values. }\end{array}$ \\
\hline
\end{tabular}


Performance evaluation and quality of service monitoring (BOYER, NEWCOMER, 2015)
Post-hiring evaluations of the private partner should consider payments based on pre-established contract performance. Quality monitoring mechanisms are needed to prevent private partners from using informational asymmetry to charge readjustments to the public partner, such monitoring can be ensured through audit reports, the appointment of a technical team responsible for contract enforcement, and through of social control.

It is then realized that the involvement of accounting in PPP control and valuation needs to occur from the decision-making process leading to the adoption of the asset delivery or service delivery model (either the traditional hiring model or PPPs). Accounting should be dedicated to understanding the social construction of the values set by each of the models, and how they fit into the socio-political context, assessing at all stages of implementation (through the audit process) the nature and extent risk transfer and, eventually, the VfM assessment (OPARA; ROUSE, 2018).

The Manual on Government Deficit and Debt (MGDD, 2016) applied to European Union countries also acknowledges their concern about the perceived complexity of accounting rules regarding PPP accounting and the difficulties in understanding how they apply to specific projects (considering that a PPP can range from designing and building infrastructure such as a school or hospital to providing public services, it is difficult to generalize results and assessments). According to this manual, the decision of the public sector to obtain structures and services through PPPs is often influenced by expectations regarding their accounting treatment (considering the impact on government debt and deficit values). Given these considerations, uncertainties on how to evaluate a PPP on an accounting basis can therefore create difficulties and delays in the various phases of project planning, preparation and implementation (MGDD, 2016).

These uncertainties about how to proceed with accounting may also be reflected by the subjectivity of the standard itself, which requires professional judgment to classify control, risks, and the fair value of the constructed enterprises. It is necessary to detail the modality of risk (which involves subjectivity in its measurement, classification and allocation among partners); the control exercised over the assets involved in the partnership (having or not controlling the assets is the determining factor for recording the asset in the public balance sheets) (MGDD, 2016).

When the assumption of benevolent government is relaxed, according to the assumptions made by TEP, the decisions of public actors can be affected by opportunistic behavior and/or external pressures (BUSO; MARTY; TRAN, 2017). This influence can lead governments to a choice that is not necessarily cost-effective, damaging decision-making and inefficient allocation of public resources.

To try to avoid this opportunistic behavior, more targeted and detailed regulation of PPPs is needed to improve some of their functions, such as: better conflict management 
between parties; protection and solution to possible customer and user complaints; protection of the public interest in the inevitable renegotiations throughout the contract; allow better, simpler and more transparent contracts (MARQUES, 2017).

\section{FINAL REMARKS}

This theoretical essay had as its main objective to identify and discuss the advances, limitations and perspectives pointed by international researches to improve the accountability and evaluation aspects of PPPs. To this end, a discussion was elaborated in the light of Public Choice Theory, inserting the trend within the global movement known as New Public Governance. A historical approach was taken to emphasize the emergence of PPPs and then to understand their main characteristics and challenges, emphasizing aspects of accountability and accounting within the public/private dichotomy. The motivation for the issue, its questions and challenges is timely as the number of PPP contracts has entered a growing wave in many countries.

In a world context of economic crises, the functions of the state were retracted because of the scarcity of resources, but once stability is restored, they are once again expanded, under a new form of governance in which the state becomes one amongst many actors acting in favor of the citizen and social welfare.

In this sense, a PPP cannot be defined simply as a business transaction, but as a longterm contractual relationship, where both partners learn over time, where the informational asymmetry between the parties needs to be lowered and implemented mechanisms for governance and monitoring to ensure the smooth running of contracts.

Thus, the theoretical contribution of this article uses the justifications of the Public Choice Theory to emphasize the need for accountability and the defense of the public interest in relations between the State and private partners, considering that such relations can alter the notions of balance and power in a partnership. Also considering the postmodern contributions of the NPM and NPG movements, it is possible to see an institutional view of the character of the partnerships, in which the expected benefits can face "problems of public choices". Another theoretical reflection that is expected to contribute is the inclusion of partnerships in the role of the regulatory State (no longer a provider), which is responsible for ensuring that partnerships are a choice based on VfM studies, with an efficient allocation of resources.

Given that TEP's assumptions for PPPs can be seen as a way to circumvent the public budget and achieve short-term political objectives, a rigorous evaluation and control process must be established in Brazil to ensure the cost-benefit behind the decision, whether or not to opt for a partnership, and to ensure the quality of the contracted service, in accordance with the democratic values of the public sector, especially in the defense of the public interest. 
Regarding the role of accounting in the evaluation and control of partnerships, it is clear that there is a need to examine the reports, statements and bids that led to the hiring of PPPs and their various peculiarities and types in order to strike a balance between private and public interests and benefits. Bodies such as the IASB have focused on regulating liabilities and assets as a result of partnership agreements, but there is still a lot of subjectivity about how these records that are being made with respect to the long-term characteristic of contracts and the allocation of risks in a fair and clear fashion. In Brazil, the literature on PPPs is still incipient, so that no research has been conducted to examine the clarity and objectivity of the accounts and audits of current PPP contracts, which can be pointed as a research agenda.

Some of the authors who pointed out a research agenda for the topic (HODGE; GREVE; BOARDMAN, 2017; HODGE; GREVE, 2017; MORAVIEV; KAKABADSE, 2016) agree that governments adopt several different contractual arrangements, establishing different risk-sharing, different financing arrangements and transparency regimes on how best to deal with contract risks or how to achieve better governance outcomes. So, for each different goal that you want to achieve with a PPP, different characteristics can be observed depending on the reality of each government.

In this sense, future research could be conducted using innovative methods as suggested by Caperchione, Demirag and Grossi (2017). Case studies and interviews can be used to further investigate which changes in accounting statements and accountability would best be leveraged in hybrid organizations.

As a final perspective, in accountability processes, it is necessary to ensure that the dual objectives of hybrid organizations are protected. Given the changes proposed by movements such as NPM and NPG, it should be noted that what constitutes an advantage from the point of view of the processes of generating public services must be properly concatenated with the perspective of accountability and public responsibility, so that that better results in public service delivery and infrastructure construction are in balance with democratic values and accountability to citizens.

\section{REFERENCES}

ANDON, P. Accounting-related Research in PPPs/PFIs: Present Contributions and Future Opportunities. Accounting, Auditing, Accountability Journal, v. 25, n. 5, pp. 876-924, 2012, <https://doi.org/10.1108/09513571211234286>.

ANGELIS, C. T. A emergência da reforma do Estado brasileiro: A governança compartilhada e o modelo do Novo serviço público. Planejamento e políticas públicas, v. 45 n. 1, pp. 1446, 2015. 
BOATENG, C. A.; STAFFORD, A.; STAPLETON, P. The role of structure in manipulating PPP accountability. Accounting, Auditing, Accountability Journal, v. 30, n. 1, pp. 119-144, 2017, <https://doi.org/10.1108/AAAJ-01-2014-1590>.

BOVAIRD, T. Public-Private Partnerships: From Contested Concepts to Prevalent Practice. International Review of Administrative Sciences, v. 70, n. 2, pp. 199-215, 2004, < http://dx.doi.org/10.1177/0020852304044250>.

BOYER, E. J.; NEWCOMER, K. E. Developing government expertise in strategic contracting for public-private partnerships. Journal of Strategic Contracting and Negotiation, v. 1, n. 2, pp. 129 - 148, 2015, <http://dx.doi.org/10.1177/2055563615592739>.

BRINKERHOFF , D. W.; BRINKERHOFF , J. M. Public-private partnerships: perspectives on purposes, Publicness, and good Governance. Public administration and development, v. 31, n. 1, pp. 2-14, 2011, <https://doi.org/10.1002/pad.584>.

BUCHANAN, J. M. The pure theory of government finance: a suggested approach. Journal of Political Economy, v. 57, n. 2, pp. 496-506, 1949, <https://www.jstor.org/stable/1826554>.

BUCHANAN, J. M. E. Musgrave, R. A. Public finance and public choice, two contrasting visions of the state. Cambridge, Mass e London, The MIT Press, 1999.

BUSO, M. MARTY, F. TRAN, P. T. Public-private partnerships from budget constraints: Looking for debt hiding? International Journal of Industrial Organization, v. 51, n. 3, pp. 56-84, 2017, <https://doi.org/10.1016/j.ijindorg.2016.12.002>.

CAPERCHIONEA, E.; DEMIRAG, I.; GROSSI, G. Public sector reforms and public private partnerships: Overview and research agenda. Accounting Forum, v. 41, n. 1, pp. 1-7, 2017, <https://doi.org/10.1016/j.accfor.2017.01.003>.

FOMBAD, M.C. Enhancing accountability in public-private partnerships in South Africa. iSouthern African Business Review, v. 18, n. 3, pp. 66-87, 2014. 
FORRER, J.; KEE, J. E.; NEWCOMER, K. E.; BOYER, E. Public-Private Partnerships and the Public Accountability. Question, Public Administration Review, v. 70, n.3, pp. 475482, 2010, <http://dx.doi.org/10.1111/j.1540-210.2010.02161.x>.

GREVE, C.; HODGE, G. A. The Logic of Public-Private Partnerships : The Enduring Interdependency of Politics and Markets. / In. Anais. THE 19TH. ANNUAL CONFERENCE OF INTERNATIONAL RESEARCH SOCIETY FOR PUBLIC MANAGEMENT. IRSPM 2015, Birmingham, United Kingdom.

GRIMSEY, D.; LEWIS, M. K. Accounting for Public Private Partnership. Accounting Forum v. 26 n. 3,4, pp. 1-21, 2002, <http://doi/10.1111/1467-6303.00089>.

GROSSI, G.; THOMASSON, A. Bridging the accountability gap in hybrid organizations. The case of Malmö Copenhagen Port. International Review of Administrative Sciences, v. 81, n. 3, pp. 604-620, 2015, <http://dx.doi.org/10.1177/0020852314548151>.

HEALD, D. A.; GEORGIOU, G. The Substance of Accounting for Public- Private Partnerships Financial Accountability. Management, v. 27, n. 2, pp. 217-247, 2011, <http://dx.doi.org/10.1111/j.1468-0408.2011.00523.x>.

HIRATA, T. PPPs são bombas-relógio sobre o caixa público. Disponível em: $<$ https://www1.folha.uol.com.br/mercado/2018/05/ppps-sao-bombas-relogio-sobre-o-caixapublico.shtml> Acesso em: 8 de novembro de 2019.

HOOD, C. A Public Management for All Seasons?, Public Administration, v. 69, n. 3 pp. 19-27, 1991, <http://doi/10.1111/j.1467-9299.1991.tb00779.x>.

HODGE, G. A.; GREVE, C. The challenge of public-private partnerships: learning from international Experience Hardcover. Cheltenham, UK: Edward Elgar Publishing, 2005.

HODGE, G. A.; GREVE, C. Public-Private Partnerships: An International Performance Review. Public Administration Review, v. 67, n. 03, pp 545-58, 2007, $<$ http://10.1111/j.1540-6210.2007.00736.x>. 
HODGE, G. A.; GREVE, C.; BOARDMAN, A. E. Public-Private Partnerships: The Way They Were and What They Can Become. Australian Journal of Public Administration, v. 76, n. 3, pp. 273-282, 2017a, <http://10.1111/1467-8500.12260>.

HODGE, G. A.; GREVE, C. On Public-Private Partnership Performance: A Contemporary Review. Public Works Management, Policy, v. 22, n. 1, pp. 55-78, 2017, < http://10.1177/1087724X16657830>.

HODGE, G. A., GREVE, C. BIYGAUTANE, M. Do PPP's work? What and how have we been learning so far? Public Management Review, v. 20, n. 8 pp. 1105-1121, 2018, < http://10.1080/14719037.2018.1428410>.

International Accounting Standards Board - IASB. IFRIC 12: Service Concession Arrangements, 2006. Disponível em: 〈http://eifrs.ifrs.org/eifrs/bnstandards/en/IFRIC12.pdf> Acesso em: 20 de janeiro de 2019.

International Public Sector Accounting Standards Board - IPSASB. Accounting and Financial Reporting for Service Concession Arrangements - Consultation Paper, 2011. Disponível em <https://www.ifac.org/system/files/publications/exposure-drafts/00288.pdf>. Acesso em 20 de janeiro de 2019.

MANUAL ON GOVERNMENT DEFICIT AND DEBT, MGDD. Long Term Contracts Between Government Units And non-Government Partners (Public Private Partnerships). Eurostat, 2016.

MANUAL DE CONTABILIDADE APLICADA AO SETOR PÚBLICO, MCASP. Aplicado à União e aos Estados, Distrito Federal e Municípios / Ministério da Fazenda, Secretaria do Tesouro Nacional. - 9a ed. - Brasília: Secretaria do Tesouro Nacional, Subsecretaria de Contabilidade Pública, Coordenação-Geral de Normas de Contabilidade Aplicadas à Federação, 2019.

MANUAL DE DEMONSTRATIVOS FISCAIS, MDF. Aplicado à União e aos Estados, Distrito Federal e Municípios / Ministério da Fazenda, Secretaria do Tesouro Nacional. - 
10ª ed. - Brasília: Secretaria do Tesouro Nacional, Subsecretaria de Contabilidade Pública, Coordenação-Geral de Normas de Contabilidade Aplicadas à Federação, 2019.

MARQUES, R. C. Why not regulate PPPs? Utilities Policy, v. 48, n. 4, pp. 141-148, 2017, <https://doi.org/10.1016/j.jup.2017.04.003>.

MARSILO, M.; CAPPELLARO, G.; CUCCURULLO, C. The Intellectual Structure Of Research Into PPPs. Public Management Review, v. 13, n. 6, pp. 763-782, 2011, <https://doi.org/10.1080/14719037.2010.539112>.

MÁXIMO, L. PPPs têm recorde de projetos, mas apenas três avançam. Disponível em: $<$ https://www.valor.com.br/brasil/5239665/ppps-tem-recorde-de-projetos-mas-apenas-tresavancam>. Acesso em: 8 de novembro de 2019.

MOURAVIEV, N.; KAKABADSE N. K. Conceptualising public-private partnerships A critical appraisal of approaches to meanings and forms. Society and Business Review, v. 11, n. 2, pp. 155 - 173, 2016, <https://doi.org/10.1108/SBR-04-2016-0024>.

MOSCARIELLO, N.; CINQUE, E. The economic effects of new PPP accounting treatments: A critical analysis of the IPSAS 32. Global Business and Economics Review, v. 18, n..3/4, pp.310 - 319, 2016, <https://doi.org/10.1504/GBER.2016.076237>.

MONTEIRO, R. S. Risk Management. In International Handbook on Public-Private Partnerships. Edited by Hodge, G. A.; Greve, C.; Boardman, A. E. Edward Elgar Cheltenham, UK・ Northampton, MA, USA 2010.

NBC TSP 05. Contratos de Concessão de Serviços Públicos: Concedente. Diário Oficial da União, Brasília, DF, 6 de dezembro de 2016. Disponível em: <http://www1.cfc.org.br/sisweb/SRE/docs/NBCTSP05.pdf>. Acesso em 05 de maio de 2019.

OPARA, M.; ROUSE, P. The perceived efficacy of public-private partnerships: A study from Canada. Critical Perspectives on Accounting, v. 58, n. 2, pp. 77-99, 2018, <https://doi.org/10.1016/j.cpa.2018.04.004>. 


\section{ORGANISATION FOR ECONOMIC COOPERATION AND DEVELOPMENT.}

Fomentando o crescimento inclusivo da produtividade na América Latina. Publishing Paris, 2014. Disponível em: <http://www.oecd.org/economy/fomentando-o-crescimentoinclusivo-da-produtividade-na-america-latina.pdf>. Acesso em 10 de janeiro de 2018.

OSBORnE, S. P. The New Public Governance?: Emerging Perspectives on the Theory and Practice of Public Governance Paperback. Routledge, New York and London 2009.

OSTROM, V. Public choice: A different approach to the study of public administration. Public Administration Review, v. 31, n. 2, pp. 203-216, 1971, <https://doi.org/10.2307/974676>.

PETERS, G.; PIERRE, J. (org). Administração Pública: coletânea. São Paulo: Unesp. Brasilia: ENAP, 2010.

PINHEIRO, F. M. G.; PINHO, J. A. G.; BRUNI, A. L. Accountability em parcerias públicoprivadas: espaços para avanços em unidades hospitalares sob gestão direta e em regime de parceria. Organizações e Sociedade, v. 25, n. 84, pp.155-174, 2018, <http://dx.doi.org/10.1590/1984-9240848>.

POllitT, C.; BOUCKAERT, G. Public Management Reform. A Comparative Analysis-New Public Management, Governance, and the Neo-Weberian State. Oxford University Press: Oxford, 2011.

REYNAERS, A. M., GRIMMELIKHUIJSE, S. Transparency in public-private partnerships: Not so bad after all? Public Administration, v. 93, n. 3, pp. 609-626, 2015, <https://doi.org/doi:10.1111/padm.12142>.

THAMER, R.; LAZZARINI, S. G. Projetos de parceria público-privada: fatores que influenciam o avanço dessas iniciativas. Revista de Administração Pública, v. 49, n. 4, pp. 819-846, 2015, <http://dx.doi.org/10.1590/0034-7612119746>.

VALERO V. Government opportunism in public-private partnerships. Journal of Public Economic Theory, v. 17, n. 1, pp. 111-135, 2017, <http://dx.doi.org/10.1111/jpet.12105>. (c) (1) $\Theta$ REAd | Porto Alegre - Vol. 26 - N. ${ }^{\circ} 1$ - Janeiro / Abril 2020 - 114-136. 
VIANA, L.; SARMENTO, J. M.; MOREIRA, J. A.; ALVES, P. The impact of Public Private Partnerships on public accounts: the Portuguese roads sector. In: Anais.. XII CICA, Aveiro, Portugal, 2017. Disponível em:

<https://www.occ.pt/dtrab/trabalhos/xviicica/finais_site/213.pdf>.

VILLANI, E.; GRECO, L.; PHILLIPS, N. Understanding Value Creation in Public-Private Partnerships: A Comparative Case Study. Journal of Management Studies, v. 54, n. 6, p. 876-905, 2017, <http://doi:10.1111/joms.12270>.

WANG, H.; XIONG, W.; WU, G.; ZHU, D. Public-private partnership in Public Administration discipline: a literature review. Public Management Review, v. 20, n. 2, p. 293-316, 2017, <https://doi.org/10.1080/14719037.2017.1313445>. 